\title{
Female sex pheromone gland of the boxwood leafminer, Monarthropalpus buxi (Diptera: Cecidomyiidae): Morphological and behavioural evidence
}

\author{
Paola RIOLO ${ }^{1}$, SARa RUSCHIONI ${ }^{1}$, Roxana L. MINUZ ${ }^{1}$, Roberto ROMANI ${ }^{2}$ and NUNZIO ISIDORO ${ }^{1 *}$ \\ ${ }^{1}$ Dipartimento di Scienze Agrarie, Alimentari e Ambientali, Università Politecnica delle Marche,Via Brecce Bianche, 60131 \\ Ancona, Italy; e-mails: p.riolo@univpm.it; s.ruschioni@univpm.it; roxana.minuz@gmail.com; n.isidoro@univpm.it \\ ${ }^{2}$ Dipartimento di Scienze Agrarie e Ambientali, Università di Perugia, 06121 Perugia, Italy; e-mail: rromani@unipg.it
}

Key words. Diptera, Cecidomyiidae, gall midge, secretory structure, ultra-structure, reproductive biology

\begin{abstract}
Morphological studies were carried out to determine whether females of the boxwood leafminer, Monarthropalpus buxi (Laboulbène) (Diptera: Cecidomyiidae) have a pheromone gland, its position and ultra-structure. In addition, the reproductive behaviour of this gall midge was studied in the laboratory in a wind-tunnel. The source of the sex pheromone was identified as the epidermis of the inter-segmental membrane between the $8^{\text {th }}$ and $9^{\text {th }}$ abdominal segments of females. The epidermis there was hypertrophied and consisted of a unicellular layer of secretory cells with ultra-structural features that include a well developed smooth endoplasmic reticulum and Golgi complexes that are typical of pheromone-producing glands. At adult emergence the sex ratio was $1: 1$. The virgin females extruded their ovipositor and moved it slowly (visible using a video-camera at high magnification), which was followed by mating. The females were monogamous, while the males usually mated several times with different females. Wind-tunnel bioassays using virgin females, ovipositor-ectomised virgins and mated females provided further evidence that virgin females produce a sex pheromone.
\end{abstract}

\section{INTRODUCTION}

The boxwood leafminer, Monarthropalpus buxi (Laboulbène) (Diptera: Cecidomyiidae), is a serious pest of boxwood in nature, gardens and plant nurseries. The females of this gall midge have a hard (sclerified), short and hook-like ovipositor that is used to insert eggs into the tissues of young boxwood leaves. This gall midge starts emerging in early May and continues until about the beginning of June, normally between 04.00 and 08.00 hours (Brewer et al., 1984). The larvae bore into the parenchyma of the leaves. The mined leaves appear discoloured and blistered and often turn yellow, which reduces the aesthetic value of the plant. Heavily infested plants often attract predatory birds that rip open the galls to eat the larvae. This collateral damage can result in greater damage than that caused by the leafminer (Batdorf, 1994).

Even if chemical control can effectively reduce the population of $M$. buxi, this is not a practical solution for private and public gardens for which we need environmentally friendly ways of controlling this pest. In addition, insecticides have mixed effects, because gall midges and their parasitoids are indiscriminately killed (Del Bene et al., 1995). An alternative way of reducing the damage caused by this pest is to use resistant varieties of boxwood (D'Eustachio \& Raupp, 2001). Another possibility is to use pheromone-based integrated pest management strategies, as is already used for other gall midges of economic importance (Gagné, 1989, 1994; Harris \& Foster, 1999; Hall et al., 2012).
In Cecidomyiidae, sex calling of males by females is reported for Mayetiola destructor Say (Enoch, 1891; Cartwright, 1922) and a "chemotropic factor" is hypothesised as a means of attracting males to conspecific females in Rabdophaga terminalis (Loew) (Barnes, 1932) and Rabdophaga triandraperda Barnes (Barnes, 1935). The existence of female-produced sex pheromones has been demonstrated for 10 phytophagous species (Harris \& Foster, 1999; Hall et al., 2012) and one zoophagous species (van Lenteren et al., 2002). The components of the female sex pheromones of 17 species of gall midges have also been identified and shown to attract conspecific males in field experiments and/or laboratory bioassays (Hall et al., 2012; Fitzpatrick et al., 2013). The sex pheromone gland is in the region of the ovipositor. In several species, this consists of the last three abdominal segments (the $8^{\text {th }}, 9^{\text {th }}$ and $10^{\text {th }}$ uromeres) (Harris \& Foster, 1999), while in four species, these glands are located in the epidermis of the inter-segmental membrane that connects the $8^{\text {th }}$ and $9^{\text {th }}$ abdominal segments (Solinas \& Isidoro, 1991, 1996; Isidoro et al., 1992; van Lenteren et al., 2002).

Of note is that in all of the species for which the location of the sex pheromone gland is known, the females have soft, tapered, telescoped and flexible ovipositors that allow them to insert eggs into narrow places, such as among bud scales or between parts of growing buds (Kieffer, 1900; Gagné, 1989).

For $M$. buxi, little is known about its reproductive behaviour and even less about the existence (and possible role) of a sex pheromone in this species. The aims of the

\footnotetext{
* Corresponding author.
} 
present study were to determine whether females of this species of gall midge, which has a hard and stiff ovipositor that is modified for inserting eggs directly into plant tissue, produce a sex pheromone and the position and ultra-structure of the pheromone gland. In addition, the mating behaviour and responses of males of $M$. buxi to the female sex pheromone in the laboratory are described and the sex ratio determined.

\section{MATERIAL AND METHODS}

\section{Sources of the adult midges}

The adult gall midges were collected from branches of boxwood shrubs with infested leaves in private and public gardens at two different localities (Ancona and Perugia districts) in central Italy, in April and May 2010. Infested branches ( 200) were placed in small jars containing tap water, sealed with cotton wool, which were kept in cages $(46 \times 37 \times 32 \mathrm{~cm})$ that had three metallic grid walls and a Plexiglas front wall. The cages were kept in a climatic chamber (Binder KBWF 240, Tuttlingen, Germany) at a temperature of $25^{\circ} \mathrm{C}$, relative humidity of $65 \%$ to $75 \%$ and a photoperiod of $16 \mathrm{~L}: 8 \mathrm{D}$.

\section{Anatomy and ultrastructure}

For the scanning electron microscopy (SEM), 10 newly emerged females were anaesthetized in $\mathrm{CO}_{2}$, immersed in $50 \%$ ethanol and kept overnight at $4^{\circ} \mathrm{C}$. After dehydration through a graded ethanol series (Panreac, Barcelona, Spain), the specimens were critical point dried in a Balzers Union CPD 020 unit and gold coated in a Balzers Union SCD 040 unit (Balzers, Vaduz, Liechtenstein) and finally examined using a Philips XL 30 scanning electron microscope (FEI Company, Eindhoven, The Netherlands). For transmission electron microscopy (TEM), 10 newly emerged virgin females were anaesthetised in $\mathrm{CO}_{2}$ and immersed in $2.5 \%$ glutaraldehyde in a $0.1 \mathrm{M}$ cacodylate buffer with $5 \%$ sucrose $(\mathrm{pH} 7.2-7.3)$. The ovipositors were then excised and kept in the same fixative for $3 \mathrm{~h}$ at $4^{\circ} \mathrm{C}$. After rinsing overnight in cacodylate buffer, the specimens were postfixed in $1 \%$ osmium tetroxide for $1 \mathrm{~h}$ at $4^{\circ} \mathrm{C}$ and rinsed in the same buffer. Dehydration through a graded ethanol series was followed by embedding in Epon-Araldite with propylene oxide as the bridging solvent. Thin sections were made using a diamond knife (Drukker, Cuijk, The Netherlands) on a "Nova" ultramicrotome (LKB, Bromma, Sweden) and mounted on collodium-coated 50-mesh grids. Finally, the sections were stained with uranyl acetate (20 min, room temperature) and lead citrate ( $5 \mathrm{~min}$, room temperature) and then examined using a Philips 208 electron microscope (FEI Company, Eindhoven, The Netherlands). Digital photographs (1376-1032 pixels, 8b, uncompressed greyscale TIFF files) were obtained using a highresolution digital camera MegaViewIII (SIS and Olympus, Tokyo, Japan) connected to the electron microscope.

\section{Mating behaviour and sex ratio}

Branches of boxwood with infested leaves were positioned in five cages $(\sim 40$ branches/cage), as described above. Immediately upon emergence and before mating, the adults were collected, separated according to sex, based on antennal dimorphism, isolated individually in a $6-\mathrm{ml}$ glass vials that were closed with cotton wool and counted on a daily basis.

Virgin males and females $(n=10$ each) were placed in a smaller plastic cage $(25 \times 35 \times 35 \mathrm{~cm})$ that contained moist sand (20-mm deep) and 10 boxwood branches. The midges were observed for $2 \mathrm{~h}$, which were repeated five times. Moreover, paired virgin males and females $(n=13$ each) of $M$. buxi were placed separately in different glass cylinders $(15 \times 8 \mathrm{~cm})$ and observed. The mating behaviour was observed and videorecorded (Sony SSC M370 CE) during the scotophase, using a $20-\mathrm{W}$ spotlight for illumination. The cages and the cylinders were kept in a climatic chamber under the same conditions as described above.

\section{Wind-tunnel bioassays}

Bioassays were carried out in a Plexiglas wind tunnel $(189 \times$ $60 \times 62 \mathrm{~cm}$ ) (Geervliet et al., 1994) to determine whether the females emit volatiles that are attractive to the males. Two glass cylinders $(10 \times 15 \mathrm{~cm})$ closed with nylon gauze at both ends were positioned inside the wind tunnel, with each cylinder representing either a blank or the test material. The air flowed through the two cylinders at $0.2 \mathrm{~m} / \mathrm{s}$. The wind tunnel was indirectly illuminated with a fluorescent light tube, with an intensity of 100 lux at the point where the males were released.

There were three different treatments: (1) blank (empty cylinder) versus virgin females $(n=10)$; (2) virgin females versus females $24 \mathrm{~h}$ after mating ( $n=10$ each); (3) virgin females versus virgin ovipositor-ectomised females $(n=10$ each). Fifty males were used in each treatment and used only once. Before the bioassays, each male was isolated in a small glass tube plugged with wet cotton wool and left to acclimatize to the conditions of the wind-tunnel room for at least $60 \mathrm{~min}$. The males were then placed $80 \mathrm{~cm}$ downwind from the cylinders in an open horizontal glass cylinder $(20 \times 15 \mathrm{~cm})$. After every 10 males, the cylinders were switched to avoid a positional bias. At the end of each trial all of the cylinders were washed with detergent, rinsed with distilled water and absolute ethanol and kept overnight at $200^{\circ} \mathrm{C}$.

The wind-tunnel observations of the male flight behaviour were video recorded. Their flight duration was recorded until they reached the source (blank or test material). Observations stopped when the male touched the gauze on the cylinders more than twice or when the male landed on the wind-tunnel walls.

\section{Statistical analysis}

Data obtained from the wind tunnel behavioural assays were analyzed using two-tailed $\chi^{2}$ tests $\left(\mathrm{H}_{0}\right.$ : insects do not show preference for any of the test cylinders). The significance level of the statistical tests was set at $P<0.05$.

\section{RESULTS}

\section{Anatomy and ultrastructure}

The ovipositor of females of $M$. buxi is relatively short and "telescopic" and consists of the last three abdominal segments (Fig. 1A, B). The $8^{\text {th }}$ uromere has a tubular shape, is entirely membranous and has a smaller diameter than the $7^{\text {th }}$ uromere. The $9^{\text {th }}$ uromere has a bulb-like shape with a smooth surface and slides in and out of the $8^{\text {th }}$ uromere during ovipositor retraction and extension. The $9^{\text {th }}$ uromere is connected to the $8^{\text {th }}$ by a sleeve-like membrane; i.e., the $8^{\text {th }}$ to $10^{\text {th }}$ inter-segmental membrane. The sclerified and hook-like $10^{\text {th }}$ uromere is used for inserting eggs into plant tissue. External SEM observations of the $8^{\text {th }}$ to $9^{\text {th }}$ inter-segmental membrane revealed a peculiar cuticular sculpture that is characterized by tiny elongated microtrichia that are arranged in small groups and distributed in a continuous regular series over the whole surface (Figs 1A, B and 2A).

The glandular area consisted of a single well-developed layer of epidermal cells that are variable in shape and size and located underneath both of the medial sides of the $8^{\text {th }}$ to $9^{\text {th }}$ inter-segmental membrane (Fig. 1C). The 

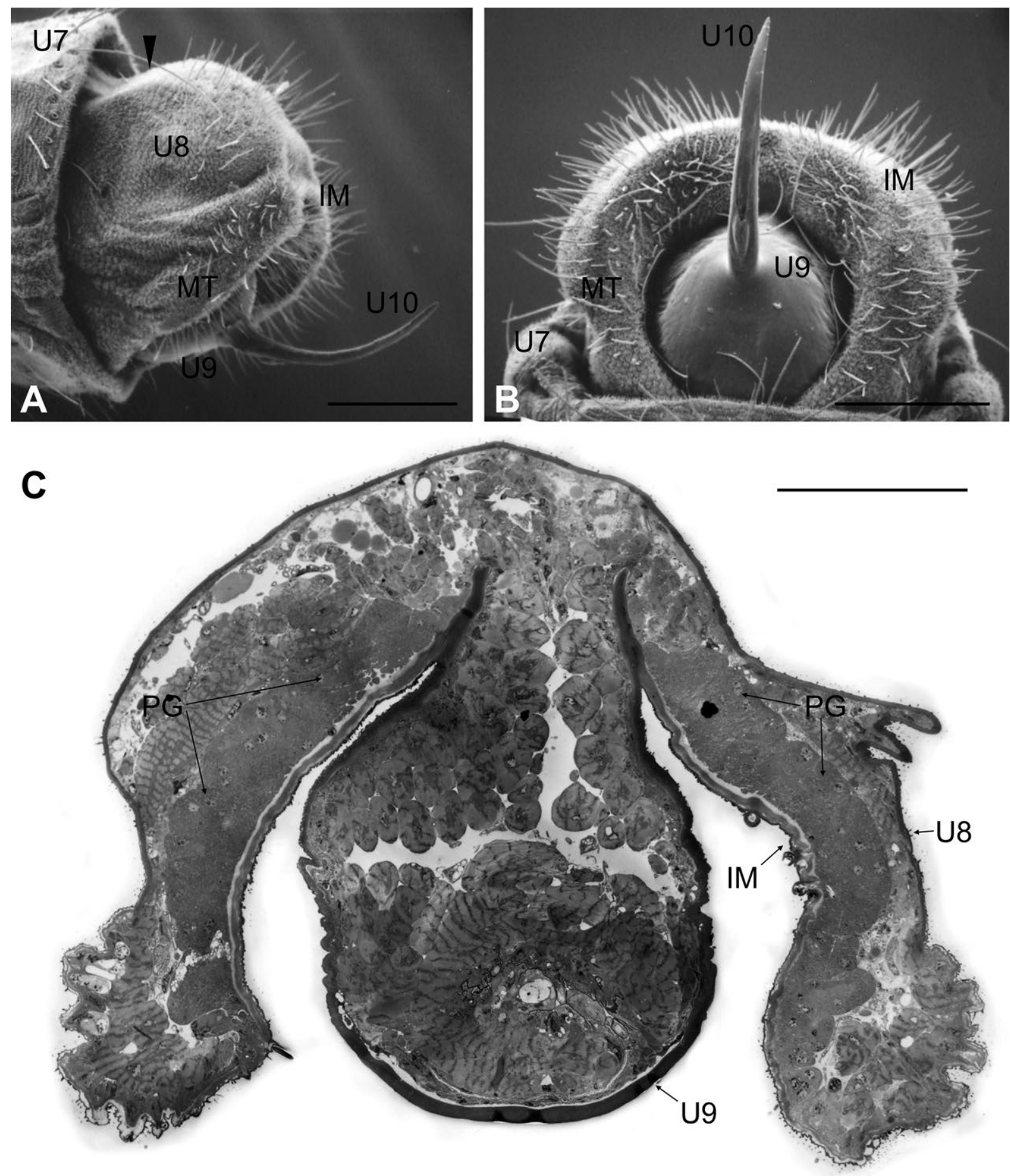

Fig. 1. Monarthropalpus buxi female. A - lateral view of last abdominal segments; B - ventral view of last abdominal segments; $\mathrm{C}$ - cross-section of last abdominal segment, at the level indicated by the arrowhead in A. IM $-8^{\text {th }}$ to $9^{\text {th }}$ inter-segmental membrane; MT - microtrichia; PG - pheromone gland; U7-U10 - $7^{\text {th }}$ to $10^{\text {th }}$ uromeres, respectively. Scale bars: $100 \mu \mathrm{m}(\mathrm{A}, \mathrm{B}) ; 50 \mu \mathrm{m}(\mathrm{C})$.

pheromone-producing epithelial cell layer is delimited by a loosely arranged basal lamina between it and the haemocoel (Fig. 2A). The epithelial cells have ovoid nuclei that are usually located in the basal part of the cells (Fig. 2A, B). These epithelial cells are separated by dilated inter-cellular spaces (Fig. 2A, B). The plasma membranes of the glandular cells adjacent to the cuticle have moderately convoluted microvillar borders, which delimit small extracellular spaces (Fig. 2C). The cytoplasm is filled with islands of smooth endoplasmic reticulum that consists of tightly packed parallel tubular elements (Fig. 2D). Other typical secretory organelles include a few, notwell-developed Golgi complexes, mitochondria with conventional cristae dispersed throughout the cell and abundant clusters of free ribosomes (Fig. 2). The presence of secretory vesicles or granules was not detected in these specimens, most probably because the females were not releasing pheromone at the time they were processed for 

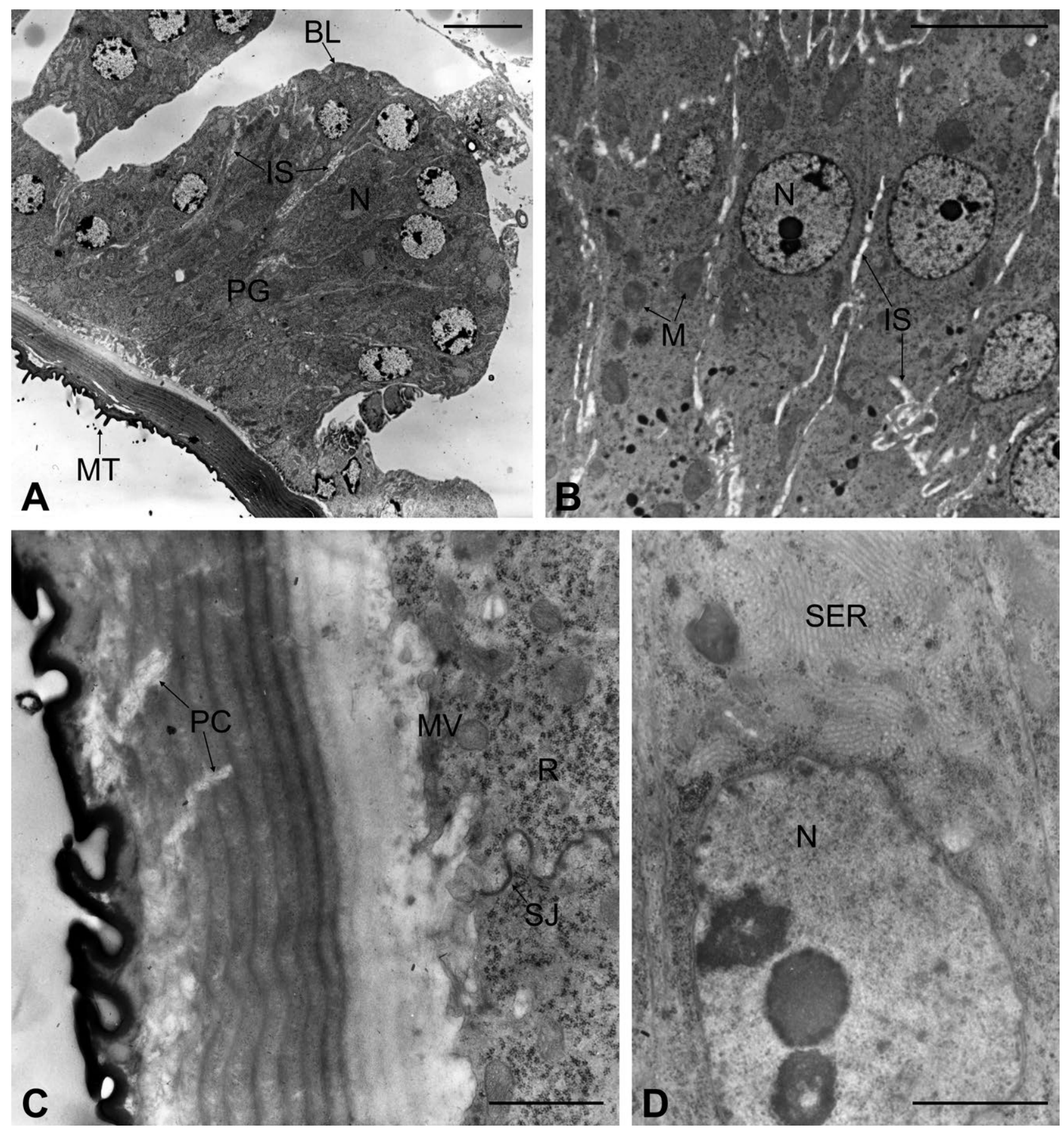

Fig. 2. Monarthropalpus buxi female. A, B - detail of a cross-section of the ovipositor, showing a general view of the glandular epithelium; $\mathrm{C}$ - detail of the cuticle overlying the glandular epidermis, showing pore canals (PC) in the laminated pro-cuticle; D detail of the perinuclear region, showing the well-developed smooth endoplasmic reticulum (SER). BL - basal lamina; IS - intercellular spaces; M - mitochondria; MT - microtrichia; MV - microvilli; N - nucleus; PG - pheromone gland; R - ribosomes; SJ - septate junction. Scale bars: $5 \mu \mathrm{m}(\mathrm{A}, \mathrm{B}) ; 2 \mu \mathrm{m}(\mathrm{C}) ; 1 \mu \mathrm{m}(\mathrm{D})$.

TEM. As is usual for epidermal tissue, the lateral cell boundaries frequently show septate junctions apically (Fig. 2C). The cuticle that overlays the glandular epidermis did not show any obvious porosity and consists of a thick electron-lucid procuticle that is easy to distinguish from the upper thin and electron-dense epicuticular layer. The epicuticle did not show any obvious porosity, while there were evident pore canals crossing the laminar procuticle (Fig. 2C).

\section{Mating behaviour and sex ratio}

At adult emergence the sex ratio was $1: 1(n=560)$. The newly emerged females and males rested on the infested leaves in which they had developed, presumably waiting for their exoskeleton to harden and in the meantime they discharged a liquid meconium that dried out within a few minutes. Then, about $40 \mathrm{~min}$ after emergence, the females hung upside down from the leaves and started calling. The females extruded the terminal part of 
TABLE 1. Responses of males of Monarthropalpus buxi recorded in a wind tunnel to virgin females, females $24 \mathrm{~h}$ after mating and ovipositor- ectomised virgin females.

\begin{tabular}{llccc}
\hline \multirow{2}{*}{ Treatment } & \multicolumn{2}{c}{ Number of males tested } & \multicolumn{2}{c}{ Number of males responding to } \\
\cline { 3 - 4 } & & & $\mathrm{A}$ & $\mathrm{B}$ \\
\hline 1 & Virgin females in A, cylinder B empty & 50 & $48^{*}$ & 0 \\
2 & Virgin females in A, mated females in B & 50 & $36^{*}$ & 0 \\
3 & Virgin females in A, O-ect virgin females in B & 50 & 0 \\
\hline
\end{tabular}

O-ect - ovipositor-ectomised; A, B - the two test cylinders for each treatment. Males responding are those that touched the gauze on the cylinders more than twice. A versus B comparisons, ${ }^{*}-P<0.001$ (two-tailed $\chi^{2}$ test).

their abdomen and moved it slowly; this extension and movement of the ovipositor was visible only when the video-camera was operated at high magnification. Soon after ovipositor extension each male flew to within 15 $\mathrm{mm}$ of a female. Subsequently, the male landed on the leaf and vibrated its wings while approaching the female from behind. The male then bent his abdomen towards and clasped the female with his genitals prior to insemination. Copulation lasted 3 to $4 \mathrm{~min}$. During copulation, both the male and the female keep their wings folded in the resting position. After mating, the male flew away while the female remained hanging from the leaf for $2 \mathrm{~h}$, before flying in search of young leaves on which to lay her eggs. Females mated only once whereas males mated several times with different females.

\section{Wind tunnel bioassays}

The males were significantly $(P<0.001)$ attracted to virgin females, but not to females $24 \mathrm{~h}$ after mating or virgin ovipositor-ectomised females (Table 1). When flying upwind the males always followed a zig-zag flight pattern and the duration of these flights was on average $40 \pm 2.8 \mathrm{~s}(n=115)$. The shortest flight time from the releasing cylinder to the odour source was $10 \mathrm{~s}$ and the longest $175 \mathrm{~s}$.

\section{DISCUSSION}

Several morphological and behavioural features of the reproductive biology of gall midges indicate an important role for chemical communication, especially as all gall midges reproduce sexually (Gagné, 1994; Hall et al., 2012). The existence of a sex pheromone gland is documented currently for only four species of gall midges, three phytophagous (Solinas \& Isidoro, 1991, 1996; Isidoro et al., 1992) and one zoophagous species (van Lenteren et al., 2002). In all of these species, the females have a soft, tapered, telescopic and flexible ovipositor, which is made up of the last three abdominal segments (the $8^{\text {th }}, 9^{\text {th }}$ and $10^{\text {th }}$ uromeres) and the sex pheromone gland of the female is located in the epidermis of the inter-segmental membrane that connects the $8^{\text {th }}$ and $9^{\text {th }}$ abdominal segments. The current study presents evidence of the existence of a sex pheromone gland in females of M. buxi, which have a hard and stiff ovipositor that is (strongly) modified for piercing plant tissue (Gagné, 1989). In M. buxi, the glandular tissue is located below the inter-segmental cuticle between the $8^{\text {th }}$ and $9^{\text {th }}$ uromeres, which is similar to the basic pattern found in Con- tarinia sorghicola (Coquillett) (Solinas \& Isidoro, 1991), Dasineura brassicae Winn. (Isidoro et al., 1992), M. destructor (Solinas \& Isidoro, 1996), Aphidoletes aphidimyza (Rondani) (van Lenteren et al., 2002), the majority of Lepidoptera (Percy-Cunningham \& MacDonald, 1987), Bruchidae (Biémont et al., 1992; Ramaswamy et al., 1995; Pierre et al., 1996) and Staphylinidae (Happ \& Happ, 1973). The thickness of the epithelium differs in the few Cecidomyiids studied, which appears to depend on the shape and size of the ovipositor: in C. sorghicola and $D$. brassicae, the glandular epithelium is very thin, while in $M$. destructor and A. aphidimyza, it is relatively thick, as in M. buxi.

The glandular tissue is composed of unicellular secretory units that are class 1 gland cells (Noirot \& Quennedey, 1974, 1991). In this type of glandular cell, the secretions simply pass through the overlying cuticle via pore canals and there are no other structures associated with the accessory cells. This appears to be a common feature of the pheromone glands of gall midges, as currently there is no evidence of glandular epithelia with secretory cells that are typical of other types of gland cells (Solinas \& Isidoro, 1991, 1996; Isidoro et al., 1992; van Lenteren et al., 2002). In addition, there are several other ultra-structural features of the secretory cells, such as a well-developed smooth endoplasmic reticulum (SER) that is widespread throughout the cytoplasm and Golgi complexes. The SER is known to produce fatty and oily products (Fawcett, 1966) and to be associated with the biosynthesis of volatile secretions (Quennedey, 1998). Hall et al. (2012) suggest that fatty acids might be intermediates in the biosynthetic pathway of the sex pheromone components of species of Cecidomyiidae, as reported for many other insects (Percy-Cunningham \& MacDonald, 1987; Tillman et al., 1999).

The structures of the various components of the pheromones of Cecidomyiidae differ. All are unbranched, which indicates a biogenetic origin from an acetate pool. The functioning of these pheromone compounds depends most commonly an acetoxy-, butyroxy-, or keto- groups. In species related to $M$. buxi (e.g., species belonging to the tribe Cecidomyiini), the components of the female sex pheromone are mono- or diacetates and acetoxyketones (Hall et al., 2012). A preliminary report (Riolo et al., 2006) of di-esters with two different alkanoyloxy groups in the pheromone of $C$. sorghicola needs to be confirmed. It is likely that the special array of microtrichia on the outer surface of the cuticle is the release site of the female 
secretions and is an adaptation that facilitates the evaporation of the pheromone when the short inter-segmental membrane is exposed.

In the present study, the sex ratio of adult $M$. buxi at emergence was $1: 1$. The sex ratio in Cecidomyiidae is generally female biased (Harris \& Foster, 1999), but is near $1: 1$ in populations of A. aphidimyza (Sell, 1976), Asteralobia sasakii (Monzen) (Tabuchi \& Amano, 2003), C. sorghicola (Baxendale \& Teetes, 1981), Dasineura rachiphaga Tripp (Prévost, 1990), M. destructor (Stuart \& Hatchett, 1991) and Mikiola fagi (Hartig) (Coutin \& Riom, 1967). After locating a virgin female the males of M. buxi first vibrate their wings and then attempt copulation immediately, which conforms to the basic pattern reported in the Cecidomyiidae (Harris \& Foster, 1999). The duration of copulation in M. buxi was $3 \mathrm{~min}$ to $4 \mathrm{~min}$, which is similar to reports for Sitodiplosis mosellana (Géhin) (Harris \& Foster, 1999) and A. aphidimyza (van Lenteren et al., 2002).

Male cecidomyiids can mate many times, but the females appear to be monogamous (Gagné, 1989) as reported, for example, for C. sorghicola (Walter, 1941), Contarinia oregonensis Foote (Miller \& Borden, 1984) and $S$. mosellana (Harris \& Foster, 1999). For female $M$. buxi, their monogamy should result in the termination of calling behaviour and production of sex pheromone (Foster et al., 1991; van Lenteren et al., 2002). This change in the behaviour of females from virgin to mated may be induced by male accessory gland substances, as previously recorded in many species of Diptera (Gillott, 1988; Hosken et al., 2009).

The reproductive biology of Cecidomyiidae is reviewed by Harris \& Foster (1999) and more recently by Hall et al. (2012). The existence of female-produced sex pheromones is reported for 11 species of Cecidomyiidae (van Lenteren, 2002; Hall et al., 2012). All of these species belong to the same sub-family, the Cecidomyiinae, which is one of the three sub-families into which the Cecidomyiidae are usually divided (Gagné, 1989, 1994). In the present study, the behavioural bioassays indicate for the first time the production of a sex pheromone by M. buxi, which also belongs to the same sub-family, the Cecidomyiinae. Unlike the other 11 species studied, in M. buxi, the female has a strongly modified ovipositor that affects the calling behaviour. Indeed, when calling, M. buxi females only extended their ovipositor very slightly, which was visible only when recording with a video camera at high magnification, whereas in the other gall midges the ovipositor is extended for its full length, which generally doubles the body length of the female (Miller \& Borden, 1981; Solinas \& Isidoro, 1991; Isidoro et al., 1992).

Over the last 10 years, great progress has been made in the identification of the female-produced sex pheromones of Cecidomyiidae. To date, the components of the female sex pheromones of 17 gall midge species have been identified and shown to attract con-specific males in laboratory bioassays and/or in field experiments (Hall et al., 2012; Fitzpatrick et al., 2013). Pheromone lures and traps have been developed for several species of midges that are of economic importance, which are already commercially available and in use for monitoring these pests (Bruce et al., 2007; Suckling et al., 2007; Cross et al., 2008, 2009; Tanasković \& Milenković, 2011). The results of the morphological and behavioural studies on $M$. buxi reported here constitute a good starting point for further studies on the identification of the components of the sex pheromone. As they markedly modify the behaviour of male adults there is a great potential for using synthetic sex pheromones of gall midges to control certain target pest by disrupting their mating, attract-and-kill or mass trapping systems (Hall et al., 2012).

ACKNOWLEDGEMENTS. Comments and suggestions of two anonymous reviewers helped us to improve this manuscript.

\section{REFERENCES}

BARNES H.E. 1932: On the gall midge injurious to the cultivation of willows. I. The bat willow gall midge (Rabdophaga terminalis H. Loew). - Ann. Appl. Biol. 19: 243-252.

BARNES H.E. 1935: On the gall midge injurious to the cultivation of willows. II. The so-called "shot hole" gall midge (Rabdophaga spp.). - Ann. Appl. Biol. 22: 86-105.

BATDORF L.R. 1994: Boxwood Handbook. America Boxwood Society, Boile, VA, 99 pp.

Baxendale F.P. \& Teetes G.L. 1981: Production of unisexual progenies by the sorghum midge, Contarinia sorghicola. Ann. Entomol. Soc. Am. 74: 412-413.

Biemont J.C., Chaibou M. \& Pouzat J. 1992: Localization and fine structure of the female sex pheromone-producing glands in Bruchidius atrolineatus (Pic) (Coleoptera: Bruchidae). Int. J. Insect Morphol. 21: 251-262.

Brewer J.W., Skuhravý V. \& Skuhravá M. 1984: Biology, distribution and control of Monarthropalpus buxi (Laboulbène) (Diptera, Cecidomyiidae). - Z. Angew. Entomol. 97: 167-175.

Bruce T.J.A., Hooper A.M., Ireland L.A., Jones O.T., Martin J.L., Smart L.E., OAKley J. \& Wadhams L.J. 2007: Development of a pheromone trap monitoring system for orange wheat blossom midge, Sitodiplosis mosellana, in the UK. Pest Manag. Sci. 63: 49-56.

Cartwright W.B. 1922: Sexual attraction of the female hessian fly (Phytophaga destructor Say). - Can. Entomol. 54: 154-155.

Coutin R. \& Riom J. 1967: Dimorphisme des galles provoquées par Mikiola fagi Hartig (Dipt. Cécid.) sur Fagus silvatica L. androcécidies et gynocécidies. - C.R. Acad. Sci. (D, Nat.) 265: 975-978.

Cross J.V., Baroffio C., Grassi A., Hall D., Łabanowska B., Milenković S., Nilsson T., Shternshis M., Tornéus C., Trandem N. \& VÉteK G. 2008: Monitoring raspberry cane midge, Resseliella theobaldi, with sex pheromone traps: results from 2006. - IOBC/WPRS Bull. 39: 11-17.

Cross J.V., Hall D.R., Shaw P. \& Anfora G. 2009: Exploitation of the sex pheromone of apple leaf midge Dasineura mali Kieffer (Diptera: Cecidomyiidae): 2. Use of sex pheromone traps for pest monitoring. - Crop Prot. 28: 128-133.

D’Eustachio G. \& Raupp M. 2001: Resistence of boxwood varietes to the boxwood leafminer, Monarthropalpus flavus (Schrank). - J. Environ. Hort. 19: 153-157.

Del Bene G., Gargani E. \& Landi S. 1995: Osservazioni sulla cecidomia del bosso, Monarthropalpus buxi (Laboulbène), in giardini storici di Firenze. - Italus Hortus 2(3): 8-16. 
ENoch F. 1981: The life history of the hessian fly. - Trans. Entomol. Soc. Lond. 39: 329-366.

Fawcett D.W. 1966: An Atlas of Fine Structure. The Cell. Its Organelles and Inclusions. W.B. Saunders, Philadelphia \& London, $448 \mathrm{pp}$.

FitzPatrick M.S., Gries R., Khaskin G., Peach D.A.H., Iwanski J. \& Gries G. 2013: Populations of the gall midge Dasineura oxycoccana on cranberry and blueberry produce and respond to different sex pheromones. - J. Chem. Ecol. 39: 37-49.

Foster S.P., Bergh J.C, Rose S. \& Harris M.O. 1991: Aspects of pheromone biosynthesis in the hessian fly, Mayetiola destructor (Say). - J. Insect Physiol. 37: 899-906.

Gagné R.J. 1989: The Plant-Feeding Gall Midges of North America. Cornell University Press, Ithaca, New York, 356 pp.

GaGnÉ R.J. 1994: The Gall Midges of the Neotropical Region. Cornell University Press, Ithaca, New York, 352 pp.

Geervliet J.B.F., Vet L.E.M. \& Dicke M. 1994: Volatiles from damaged plants as major cues in long-range host-searching by the specialist parasitoid Cotesia rebecula. - Entomol. Exp. Appl. 83: 289-297.

Gillott C. 1988: Arthropoda - Insecta. In Adyodi K.G. \& Adyodi R.D. (eds): Reproductive Biology of Invertebrates, Vol. III. Accessory Sex Glands. Oxford University Press, Oxford, and IBH, New Delhi, pp. 319-471.

Hall D.R., Amarawardana L., Cross J.V., Franke W., Boddum T. \& Hillbur Y. 2012: The chemical ecology of cecidomyiid midges (Diptera: Cecidomyiidae). - J. Chem. Ecol. 38: $2-22$.

HAPP G.M. \& HAPP C.M. 1973: Fine structure of the pygidial glands of Bledius mandibularis (Coleoptera: Staphylinidae). — Tissue Cell 5: 215-231.

Harris M.O. \& Foster S.P. 1999: Gall midges. In Hardie J. \& Minks A.K. (eds): Pheromones of Non-Lepidopteran Insects Associated with Agricultural Plants. CAB International, Wallingford, pp. 27-49.

Hosken D.J., Stockley P., Tregenza T. \& Wedell N. 2009: Monogamy and the battle of the sexes. - Annu. Rev. Entomol. 54: 361-78.

Isidoro N., Williams I.H., Solinas M. \& Martin A. 1992: Mating behaviour and identification of the female sex pheromone gland in the brassica pod midge (Dasineura brassicae Winn.: Cecidomyiidae, Diptera). - Boll. Ist. Entomol. "G. Grandi" Univ. Bologna 47: 27-48.

KiefFer J.J. 1900: Monographie des Cecidomyides d'Europe et d'Algérie. - Ann. Soc. Entomol. Fr. 69: 181-472.

Miller G.E. \& Borden J.H. 1981: Reproductive behavior of the douglas-fir cone gall midge, Contarinia oregonensis (Diptera: Cecidomyiidae). - Can. Entomol. 116: 607-618.

Noirot C. \& QuenNedey A. 1974: Fine structure of insect epidermal glands. - Annu. Rev. Entomol. 19: 61-80.

NoIRot C. \& QuenNedey A. 1991: Glands, gland cells, glandular units: some comments on terminology and classification. Ann. Soc. Entomol. Fr. 27: 123-128.

Percy J.E. \& Weatherston J. 1974: Gland structure and pheromone production in insects. In Birch M.C. (ed.): Pheromones. North Holland Publishing Company, Amsterdam, pp. 11-34.

Percy-Cunningham J.E. \& MacDonald J.A. 1987: Biology and ultrastructure of sex-pheromone producing glands. In Prestwich G.D. \& Blomquist G.J. (eds): Pheromone Biochemistry. Academic Press, New York, pp. 27-75.
Pierre D., Biémont J.C., Pouzat J., Lextrait P. \& Thibeaudeau C. 1996: Location and ultrastructure of sex pheromone glands in female Callosobruchus maculatus (Fabricius) (Coleoptera: Bruchidae). — Int. J. Insect Morphol. 25: 391-404.

Prévost Y.H. 1990: Spruce cone axis midge, Dasineura rachiphaga Tripp (Diptera: Cecidomyiidae), in cones of black spruce, Picea mariana (Mill) B. S. P. - Can. Entomol. 122: 441-447.

QUENNEDEY A. 1998: Insect epidermal gland cells: ultrastructure and morphogenesis. - Microsc. Anat. Invertebr. 11: 177-207.

Ramaswamy S.B., Shu S., Monroe W.A. \& Mbata G.N. 1995: Ultrastructure and potential role of integumentary glandular cells in adult male and female Callosobruchus subinnotatus (Pic) and C. maculatus (Fabricius) (Coleoptera: Bruchidae). -Int. J. Insect Morphol. 24: 51-61.

Riolo P., Hillbur Y., Isidoro N., Peri E., Haftmann J., Franke S. \& FRANCKE W. 2006: Electrophysiological response of sorghum midge, Contarinia sorghicola, to candidate sex pheromone compounds. In Abstracts of 22nd ISCE Annual Meeting, Barcelona, Spain. p. 81.

Sell P. 1976: Monogenie bei Aphidoletes aphidimyza (Rond.) (Diptera: Cecidomyiidae). - Z. Angew. Entomol. 82: 58-61 [in German, English abstr.].

Solinas M. \& Isidoro N. 1991: Identification of the female sex pheromone gland in the sorghum midge, Allocontarinia sorghicola (Coq.) Solinas (Diptera, Cecidomyiidae). — Redia 74: 441-446.

Solinas M. \& Isidoro N. 1996: Functional anatomy of female sex pheromone gland of Mayetiola destructor Say (Diptera, Cecidomyiidae). - Entomologica 30: 43-54.

Stuart J.J. \& HatchetT J.H. 1991: Genetics of sex determination in the hessian fly, Mayetiola destructor. - J. Hered. 82: $43-52$.

Suckling D.M., Walker J.T.S., Shaw P.W., Manning L., Lo P., Wallis R., Bell V., Sandanayaka W.R.M., Hall D.R., Cross J.V. \& El-SAYed A.M. 2007: Trapping Dasineura mali (Diptera: Cecidomyiidae) in apples. - J. Econ. Entomol. 100: $745-751$.

TABUChI K. \& Amano H. 2003: Host-associated differences in emergence pattern, reproductive behavior and life history of Asteralobia sasakii (Monzen) (Diptera: Cecidomyiidae) between populations on Ilex crenata and I. integra (Aquifoliaceae). - Appl. Entomol. Zool. 38: 501-508.

TANasković S. \& Milenković S. 2011: Monitoring the flight dynamics of raspberry cane midge Resseliella theobaldi Barnes by pheromone traps in Western Serbia. - Acta Entomol. Serbica 15: 81-90.

Tillman J.A., Seybold S.J., Jurenka R.A. \& Blomquist G.J. 1999: Insect pheromones-an overview of biosynthesis and endocrine regulation. - Insect Biochem. Mol. Biol. 29: 481-514.

van Lenteren J.C., Schettino M., Isidoro N., Romani R. \& van SCHELT J. 2002: Morphology of putative sex pheromone glands and mating behaviour in Aphidoletes aphidimyza. Entomol. Exp. Appl. 102: 199-209.

WALTER E.V. 1941: The biology and control of the sorghum midge. — USDA Tech. Bull. 778: 1-26.

Received June 7, 2013; revised and accepted September 23, 2013 